\title{
Aquatic physical and chemical characteristics of reservation and prohibited areas of mahseer (Tor douronensis Valenciennes, 1842) in Muara Bungo and Kerinci Regencies, Jambi Province of Indonesia
}

\author{
Febri Ria Safitri ${ }^{1}$, Sulistiono ${ }^{1, *}$, Sigid Hariyadi $^{1}$ \\ ${ }^{1}$ Department of Aquatic Resources Management, Faculty of Fisheries and Marine Science, IPB \\ University, Bogor, 16680, West Java, Indonesia.
}

\begin{abstract}
Masheer (Tor douronensis) is one of the important commodities, has long been known as one of the fish with a high enough value, and is loved by many people in Jambi Province and several other provinces in Indonesia. However, the ecological information of this fish is not widely known. This study examines the characteristics of aquatic physical and chemical of the reserved and prohibited area for fish in Muara Bungo and Kerinci Regencies in Jambi Province. The study was carried out from December 2018 to October 2019 at four locations, i.e., Lubuk Alai, Senamat River, and Tarutung Village, and the river outside the protected area. Aquatic physical and chemical parameters data were collected in-situ and ex-situ. The Aquatic parameters observed were temperature $25.7-30.1^{\circ} \mathrm{C}, \mathrm{pH}$ 6-7, DO 5.3-7.8, transparency $15-125 \mathrm{~cm}$, depth $25-207 \mathrm{~cm}$, turbidity $1.4-158.3 \mathrm{ppm}$, TSS $3.0-62.9 \mathrm{ppm}$, ammonia $0.08-0.76 \mathrm{ppm}$, nitrite $0.03-0.31 \mathrm{ppm}$, nitrate $0.00-0.68 \mathrm{ppm}$, and total phosphate 0.00-1.31 ppm, which were suitable for aquatic life. Based on habitat condition grouping, Lubuk Alai and Tarutung Village tend to have a higher similarity, which ammonia, transparency, depth, and total phosphate were the main components.
\end{abstract}

\section{Introduction}

The freshwaters (including rivers) in Sumatra Island have a part of the area protected by the community or the local government to conserve the fish resources in these waters to avoid extinction. The general characteristics of the prohibited waters are usually quite deep and still have water during the dry season. Some protected waters in the Sumatra region are in Muara Bungo and Kerinci, designated for mahseer (Tor douronensis Valenciennes, 1842) protection, which has high economic value. The fish are also found in Java, Kalimantan, Malaysia, Thailand, Pakistan, and India.

\footnotetext{
*Corresponding author: onosulistiono@gmail.com
} 
The mahseer is a native fish species found in rivers and lakes in the upper reaches, especially in areas that have fairly strong currents [1,2]. The condition of this fish population in nature is rarely found. Intensive fishing activities are thought to be the cause of the decline in the fish population. The sustainability of a fish population is also determined by the condition of the aquatic habitat, both physically and chemically. Changes in the habitat that are not suitable for the fish can be a threat to this fish species. The decline in the stock of the fish in nature can be caused by direct human activities through overexploitation activities or can be caused by human activities that have an impact on decreasing water quality, especially in the upstream part of the river as a habitat for these fish. Therefore, it is urgent to conduct development activities for these fish through the use of biological information $[3,4,5,6]$ and habitat conditions in nature, which are applied to cultivation conditions.

There are two terms for the protected area (for fishing) in Sumatra, namely the prohibited area (Lubuk Larangan-Indonesian) and the reservation area. The prohibited area is established traditionally by local people and managed as a conservation area based on a zonation system [7]. In the waters, fishes are forbidden to be caught at certain times. Meanwhile, reservation area (reservation-Indonesian) is a limited conservation aquatic area, wherein that area there is a prohibition on catching resources in any way, at any time and by anyone, because it functions as a preserving endemic fish and another biota.

Aquatic habitat quality and its characteristics are related to the abundance, growth, and development of aquatic organisms. This information is very important in the domestication and culture of the fish. Several studies related to the habitat of mahseer were carried out in Ciliwung River and Kuningan culture pond [8]. Studies on the mahseer habitat were also conducted in 2019, i.e., the phytoplankton community in conservation areas [9] and ecotourism development in conservation areas [10]. The purpose of this study is to reveal the water quality (physical and chemical parameters) of the reservation and the prohibited areas of the mahseer in those regencies in Jambi Province.

\section{Methodology}

\subsection{Time and location}

The aquatic physical and chemical characteristics of reservation and prohibited areas studies were conducted in December 2018, and April, July, and October 2019, at four locations, namely A. Reservation area of Lubuk Alai (in Beringin Village), B. Prohibited area of Senamat River, and C. Prohibited area in the water of Tarutung Village, and D. River which was outside the conservation area (Figure 1). Water quality was analyzed at the Aquaculture Environment Laboratory, IPB University.

\subsection{Data collection}

In-situ and ex-situ data were collected during the study. The in-situ were observed directly at the study location (field), i.e., temperature, transparency, depth, $\mathrm{pH}$, and dissolved oxygen (DO). At the same time, ex-situ data were analyzed in the laboratory, i.e., turbidity, Total Suspended Solid (TSS), nitrite $\left(\mathrm{NO}_{2}\right)$, nitrate $\left(\mathrm{NO}_{3}\right)$, ammonia $\left(\mathrm{NH}_{3}\right)$, and total phosphate $\left(\mathrm{PO}_{4}\right)$. This study used a method, sampling technique, and preservation according to APHA [11] (Table 1). 


\subsection{Data analysis}

Data on aquatic physical and chemical characteristics were compared with Amirudin (2015)[8], Government Regulation no. 22 of 2021 [12] on the Implementation of Environmental Protection and Management, and Government Regulation no. 82 of 2001 [13].

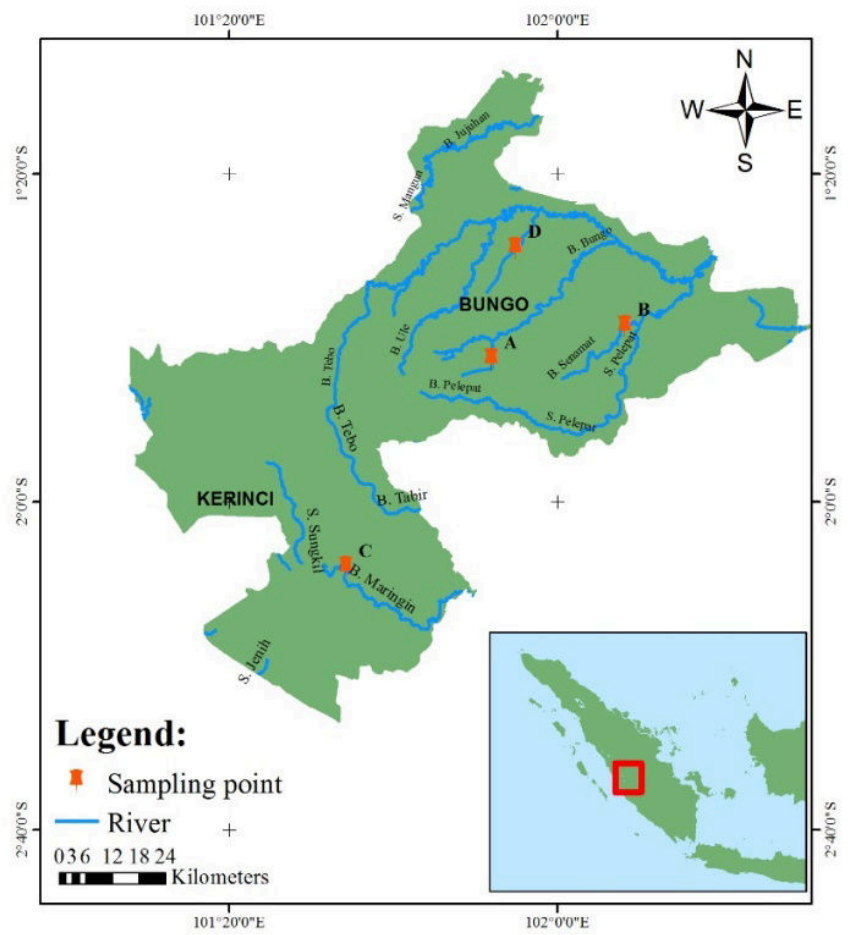

Fig. 1. Study location of mahseer reservation and prohibited areas in Bungo and Kerinci Regencies of Jambi Province.

Table 1. Methods used in the study on aquatic physical and chemical parameters of the masheer habitat.

\begin{tabular}{llll}
\hline \multicolumn{1}{c}{ Parameters } & \multicolumn{1}{c}{ Unit } & Method/Equipment & \multicolumn{1}{c}{ location } \\
\hline Turbidity & $\mathrm{NTU}$ & Nephelometric & Ex-situ (lab.) \\
Total Suspended Solid & $\mathrm{mg} / \mathrm{L}$ & Gravimetric & Ex-situ (lab.) \\
Temperature & ${ }^{\circ} \mathrm{C}$ & DO meter & field \\
Depth & $\mathrm{cm}$ & Depth (gauge) rope & field \\
Transparency & $\mathrm{cm}$ & Visual & field \\
Dissolved Oxygen (DO) & $\mathrm{mg} / \mathrm{L}$ & DO meter & field \\
$\mathrm{pH}$ & - & $\mathrm{pH}$ stick & field \\
$\mathrm{NH}_{3}$ & $\mathrm{mg} / \mathrm{L}$ & phenate & Ex-situ (lab.) \\
$\mathrm{NO}_{2}$ & $\mathrm{mg} / \mathrm{L}$ & Cadmium reduction & Ex-situ (lab.) \\
$\mathrm{NO}_{3}$ & $\mathrm{mg} / \mathrm{L}$ & Sulfanilamide & Ex-situ (lab.) \\
$\mathrm{PO}_{4}$ & $\mathrm{mg} / \mathrm{L}$ & Ascorbic acid & Ex-situ (lab.) \\
\hline
\end{tabular}


In this study, analysis on the important component was conducted using multivariate analysis as a PCA to group variables with the same diversity [14]. Water quality characteristics data between components (parameters) was described using the PCA and XLSTAT 2020 software, and it was presented in biplots. Habitat grouping was used to estimate similarity among locations [15]. Analysis on a similarity of the stations used the Minitab Application 19 and expressed by the dendrogram.

\section{Results}

\subsection{Water quality}

Aquatic habitats characterized by physical and chemical quality conditions of the waters are very important to reveal as the basis for fish development (especially aquaculture). The results of water quality observations were obtained from direct measurements in the field (temperature, $\mathrm{pH}, \mathrm{DO}$, depth, and brightness) and laboratory analysis results (turbidity, TSS, ammonia, nitrite, nitrate, and total phosphate).

The results of the water quality observations obtained are presented in Table 3 . The temperature ranged from $25.7-30.1{ }^{\circ} \mathrm{C}$ with a low value at Station $\mathrm{C}$ and a fairly high value at Station $\mathrm{D}$. The $\mathrm{pH}$ value ranged from 6-7, with a fairly low $\mathrm{pH}$ at stations $\mathrm{C}$ and $\mathrm{D}$, and High $\mathrm{pH}$ at Stations A and B. DO values ranged 5.30-7.75 mg/L, with low and high values at Station A. Water depths, ranged from $25-336 \mathrm{~cm}$, with low depths found at Station D, and quite deep at Station C. The transparency values ranged from $15-125 \mathrm{~cm}$, with a low value at Station $\mathrm{D}$ and a high value at Station $\mathrm{B}$.

Observations on turbidity and TSS ranged 1.43-158.33 NTU and 3.00-62.93 mg/L, respectively, with a low value at Station $\mathrm{D}$ and a high value at Station $\mathrm{B}$. Ammonia and nitrite levels ranged $0.08-0.76 \mathrm{mg} / \mathrm{L}$ and $0.03-0.31 \mathrm{mg} / \mathrm{L}$, respectively, with low values, found at Station B, and quite high values found at Station A. Nitrate levels ranged 0.00-0.68 $\mathrm{mg} / \mathrm{L}$, with low values at Station $\mathrm{D}$, and quite high found at Station A. In contrast, phosphate levels ranged $0.00-1.27 \mathrm{mg} / \mathrm{L}$, with a low value found at Station D and a fairly high value found at Station $C$.

Table 3. Water quality observation results were conducted at sampling locations of Bungo and Kerinci Regencies, Jambi Province.

\begin{tabular}{|c|c|c|c|c|c|}
\hline \multirow[b]{2}{*}{ Parameters } & \multirow[b]{2}{*}{ Unit } & \multicolumn{4}{|c|}{ Station } \\
\hline & & Lubuk Alai & Senamat River & Tarutung Village & $\begin{array}{c}\text { Outside } \\
\text { conservation } \\
\text { area }\end{array}$ \\
\hline Temperature & $\mathrm{C}$ & $\begin{array}{c}26.43-28.70 \\
(27.28 \pm 0.85)\end{array}$ & $\begin{array}{c}27.50-28.70 \\
(28.07 \pm 0.44)\end{array}$ & $\begin{array}{c}25.70-29.40 \\
(27,15 \pm 1.47)\end{array}$ & $\begin{array}{c}27.00-30.10 \\
(28.55 \pm 1.55)\end{array}$ \\
\hline Transparency & $\mathrm{cm}$ & $\begin{array}{l}90.00-207.00 \\
(90.00 \pm 1.04)\end{array}$ & $\begin{array}{c}15.00-50.00 \\
(15.00 \pm 5.00)\end{array}$ & $\begin{array}{c}51.00-125.00 \\
(125.00 \pm 21.79)\end{array}$ & $\begin{array}{c}25.00-28.00 \\
(26.50 \pm 1.50)\end{array}$ \\
\hline Depth & $\mathrm{cm}$ & $\begin{array}{c}90.00-207.00 \\
(127.00 \pm 47.10)\end{array}$ & $\begin{array}{c}34.00-192.00 \\
(95.50 \pm 61.14)\end{array}$ & $\begin{array}{c}88.00-337.00 \\
(164.75 \pm 101.25)\end{array}$ & $\begin{array}{c}25.00-28.00 \\
(26.50 \pm 1.50)\end{array}$ \\
\hline Turbidity & NTU & $\begin{array}{c}1.60-22.67 \\
(8.13 \pm 8.46)\end{array}$ & $\begin{array}{c}9.07-158.33 \\
(58.89 \pm 59.94)\end{array}$ & $\begin{array}{c}3.00-20.37 \\
(8.77 \pm 6.80)\end{array}$ & $\begin{array}{c}1.43-2.40 \\
(1.92 \pm 0.49)\end{array}$ \\
\hline TSS & $\mathrm{mg} / \mathrm{L}$ & $\begin{array}{c}3.00-14.93 \\
(8.99 \pm 5.08)\end{array}$ & $\begin{array}{c}3.07-62.93 \\
(33.74 \pm 28.41)\end{array}$ & $\begin{array}{c}3.00-18.70 \\
(9.67 \pm 6.81)\end{array}$ & $\begin{array}{c}3.00-8.50 \\
(5.75 \pm 2.75)\end{array}$ \\
\hline $\mathrm{pH}$ & - & $\begin{array}{c}6.00 \\
(6.00 \pm 0.00)\end{array}$ & $\begin{array}{c}6.00 \\
(6.00 \pm 0.00)\end{array}$ & $\begin{array}{c}6.00-7.00 \\
(6.25 \pm 0.43)\end{array}$ & $\begin{array}{c}6.00-7.00 \\
(6.50 \pm 0.50)\end{array}$ \\
\hline DO & $\mathrm{mg} / \mathrm{L}$ & $\begin{array}{c}5.30-7.75 \\
(6.74 \pm 1.04) \\
\end{array}$ & $\begin{array}{c}6.20-6.40 \\
(6.30 \pm 0.10) \\
\end{array}$ & $\begin{array}{c}5.63-6.87 \\
(6.30 \pm 0.54) \\
\end{array}$ & $\begin{array}{c}6.50-7.20 \\
(6.85 \pm 0.35) \\
\end{array}$ \\
\hline
\end{tabular}




\begin{tabular}{|c|c|c|c|c|c|}
\hline $\mathrm{NH}_{3}$ & $\mathrm{mg} / \mathrm{L}$ & $\begin{array}{c}0.15-0.76 \\
(0.41 \pm 0.22)\end{array}$ & $\begin{array}{c}0.08-0.41 \\
(0.35 \pm 0.16)\end{array}$ & $\begin{array}{c}0.08-0.41 \\
(0.28 \pm 0.13)\end{array}$ & $\begin{array}{c}0.39-0.44 \\
(0.42 \pm 0.03)\end{array}$ \\
\hline $\mathrm{NO}_{2}$ & $\mathrm{mg} / \mathrm{L}$ & $\begin{array}{c}0.03-0.31 \\
(0.11 \pm 0.11)\end{array}$ & $\begin{array}{c}0.03-0.22 \\
(0.08 \pm 0.08)\end{array}$ & $\begin{array}{c}0.04-0.10 \\
(0.06 \pm 0.02)\end{array}$ & $\begin{array}{c}0.04-0.29 \\
(0.17 \pm 0.13)\end{array}$ \\
\hline $\mathrm{NO}_{3}$ & $\mathrm{mg} / \mathrm{L}$ & $\begin{array}{c}0.14-0.51 \\
(0.27 \pm 0.15)\end{array}$ & $\begin{array}{c}0.08-0.68 \\
(0.42 \pm 0.22)\end{array}$ & $\begin{array}{c}0.05-0.28 \\
(0.16 \pm 0.10)\end{array}$ & $\begin{array}{c}0.00-0.23 \\
(0.12 \pm 0.12)\end{array}$ \\
\hline $\mathrm{PO}_{4}$ & $\mathrm{mg} / \mathrm{L}$ & $\begin{array}{c}0.00-1.08 \\
(0.55 \pm 0.46)\end{array}$ & $\begin{array}{c}0.00-1.31 \\
(0.58 \pm 0.52) \\
\end{array}$ & $\begin{array}{c}0.00-1.27 \\
(0.55 \pm 0.51) \\
\end{array}$ & $\begin{array}{c}0.00-0.28 \\
(0.14 \pm 0.14) \\
\end{array}$ \\
\hline
\end{tabular}

\subsection{Principles Component Analysis (PCA)}

The relationship between the study location and the aquatic environment is conveyed through multivariate analysis as PCA. In this study, we used multivariate analysis to analyze the main (water quality) parameters of the station (A-D) that affect the study location. The PCA analysis shows that the main parameters at stations A and $\mathrm{C}$ were ammonia, transparency, depth, and total phosphate. The main parameters at station B were nitrate, TSS, and turbidity. Whereas the main components at station D were nitrite and temperature (Figure 2).

\section{Biplot (axes F1 and F2: 84,73 \%)}

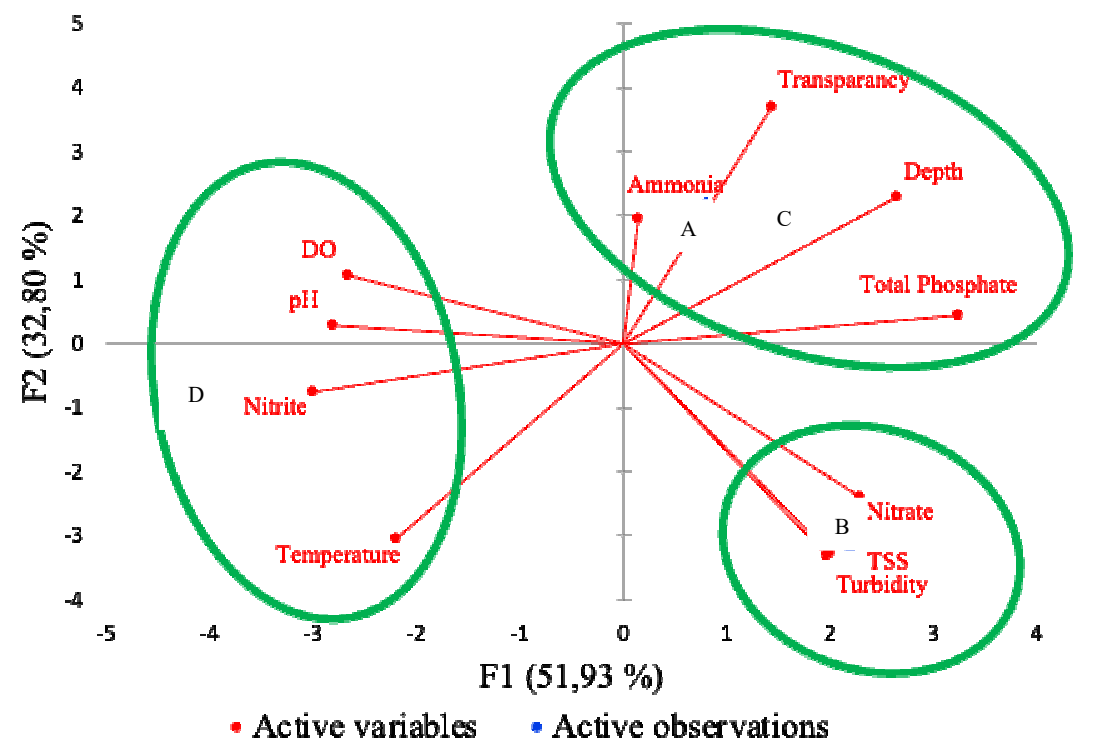

Fig. 2. Principles of Component Analysis (PCA) water quality parameters

\subsection{Habitat grouping}

The study locations grouping was carried out based on the similarity of aquatic physical and chemical characteristics (habitat) of the waters and presented in the dendrogram. There were two habitat groups, according to similarity analysis, and it is expressed in the dendrogram, i.e., group one consisted of Station A and C (similarity level $>75 \%$ ), and group two consisted of Station B and D (similarity level $<40 \%$ ) (Figure 3). 


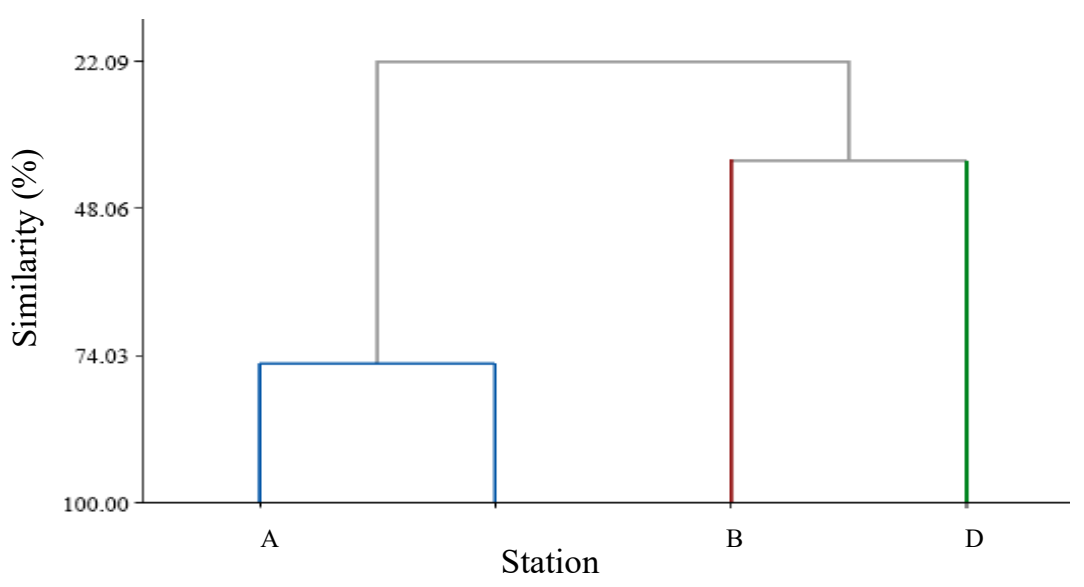

Fig. 3. Station grouping dendrogram according to water quality parameters

\section{Discussion}

Freshwater fish in Sumatra has an essential role as a source of protein for some people in that region. Even some fish species become fish of icon and are related to the cultural customs of the local community. So that, the existence of these fish should be maintained and preserved so that they can be utilized sustainably. One of the efforts to preserve these fish resources is that community and local governments have carried out habitat protection activities in certain areas where these fish are commonly found. One of these prohibited areas can be found in Bungo and Kerici Regencies.

In Bungo Regency, it is known that there is a protected area which is a remarkable fishery reserve area for mahseer for reservation and is well known among the public. This area serves as a conservation area, as well as a tourism area. In this regency, prohibited area Senamat River was also found as conservation of mahseer resources. Conserving this area is the main program of the office of Livestock and Fisheries in Bungo Regency, Jambi Province. Meanwhile, a protected area in Kerinci Regency was found in a tributary of the Batang Merangin River.

There are two terms commonly used in implementing fish conservation by the government and the community, namely reservation and prohibition areas, as a buffer habitat, fish cultivation, and other biological conservation. In the reservation area, the fish in that area cannot be caught anymore. While in the prohibited area, it can be caught within a certain period of time. Both reservation and prohibited areas are conservation systems that are local wisdom of the people, which are based on conservation aspects related to human knowledge of the resources [16]. Communities around the reservation area and prohibited area have a trust value in several fish, including mahseer [17]. There are around 197 reserves and prohibitions in Jambi Province, and about 123 of them are in Bungo Regency [18].

Assessment of habitat characteristics can be carried out by observing various aquatic physical and chemical indicators. Some physical and chemical parameters were observed in situ, and others were analyzed in the laboratory. Based on the observations, it is known that some parameters ( $\mathrm{pH}, \mathrm{DO}$, temperature) seem to be similar and were in the normal range condition. The DO values $(5-7 \mathrm{mg} / \mathrm{L})$ were also quite good for aquatic life. This condition follows other observations, at least five $\mathrm{mg} / \mathrm{L}$ for fish farming [19]. The $\mathrm{pH}$ conditions of the waters were also quite good for growth, and the optimum $\mathrm{pH}$ is 4-11 [19]. 
Water transparency was very much determined by the penetration of light entering the water. The transparency will depend on the depth of the water so that the reference is the percentage of transparency depth compared to the waters themselves. It is said to be clear if the depth of brightness is more than $80 \%$ compared to the depth of water [20]. For depth parameters, the measurement results obtained are the following [1], namely the habitat of masheer in the form of waters with a depth of 1-3 meters. For large-sized masheer, usually have their niche, which is a deep hole with a depth of more than 3 meters [1]. The observed conditions of ammonia, nitrite, nitrate, and total phosphate parameters were also good for the life of aquatic biota [13].

Water quality is an important indicator for fisheries purposes. Based on the data obtained, a significant difference was obtained for turbidity in the Senamat River in December 2018. This result is because the sampling time coincided with the rainy season and flooding, so that the river water was very swift and murky.

The results of the PCA analysis were used to determine the correlation between the components that had been grouped into three distinct component groups, namely water quality. The water quality group showed a strong correlation between $\mathrm{pH}$ with DO and TSS with turbidity and nitrates. The relationship between $\mathrm{pH}$ and DO is influenced by the ability of water to bind oxygen. When the $\mathrm{pH}$ is acidic, the oxygen solubility level will decrease and vice versa. The nutrient content of $\mathrm{N}$ in the waters will indirectly affect the TSS in the waters, which will affect the turbidity of these waters [20].

\section{Conclusion}

Mahseer (Tor douronensis) habitat is commonly in the clear waters upstream, with fairly stable water quality. The result of aquatic parameters measurement consisted of temperature $\left(25.7^{\circ} \mathrm{C}-30.1^{\circ} \mathrm{C}\right), \mathrm{pH}(6-7)$, DO $(5.3 \mathrm{mg} . \mathrm{L}-7.8 \mathrm{mg} / \mathrm{L})$, transparency $(15-125$ $\mathrm{cm})$, depth $(25-207 \mathrm{~cm})$, turbidity $(1.4-158.3 \mathrm{ppm})$, TSS (3.0-62.9 ppm), ammonia (0.08$0.50 \mathrm{ppm})$, nitrite $(0.03-0.31 \mathrm{ppm})$, nitrate $(0.00-0.68 \mathrm{ppm})$, and total phosphate $(0.00-1.31$ ppm) were generally suitable for aquatic life. Based on the habitat condition grouping, Lubuk Alai and Tarutung Village tend to have a higher similarity, which ammonia, transparency, depth, and total phosphate were the main components.

\section{References}

1. J. Subagja, Marson, BAWAL. 2, 3 (2008)

2. J. Subagja, A. Wibowo, Marson, BAWAL. 2, 4 (2009)

3. Haryono, J. Subagja, Biodivers. J. 9, 4 (2008)

4. B.A. Ingram, S. Sungan, G.J. Gooley, Y.S. Sim, D. Tinggi, S.S. De Silva, Aquac. Res. 36, 1001-1014 (2005)

5. J. Subagja, D. Radona, W. Cahyanti, S. Asih. Semah fish hatchery (Tor douronensis. Val. 1842) (in Bahasa Indonesia) (Unpublished Report, 2013)

6. Rupawan, A. Karim, Husnah, Jurnal Penelit. Perikanan Indones. 4 (1999).

7. M. Faisal, M.G. Rindarjono, C. Muryani, Jurnal GeoEco. 2, 2 (2016)

8. Amirudin, Bogor (ID): Institut Pertanian Bogor (2015)

9. F. Syafitri, Sulistiono, S. Hariyadi, Asmadi, IOP Conference Ser. Earth and Environ. Sci. 744, 1 (2021)

10. M.A. Aditya, F. Yulianda, Sulistiono, JITODE. 9, 3 (2021)

11. APHA (American Public Health Association), Standard methods for the examination 
of water and waste water including bottom sediment and sludges (American Public Health Association Inc., New York, 1989)

12. Government Regulation No. 22, Implementation of environmental protections and management (in Bahasa Indonesia) (2021)

13. Indonesian Regulation No.82, Water quality management and water pollution control (in Bahasa Indonesia) (2001)

14. A. Rufaidah, A. Effendi, Jurnal Ilmiah Edutic. 3, 2 (2017)

15. C.J. Krebs, Ecological methodology (Menlo Park: Addison-Wesley, California, 1999)

16. Triyanto, Masyarakat Limnologi Indonesia (MLI), 3 2017)

17. R.N.H. Bulmer, The Institute of Applied Social and Economic Research, 59-78 (1982)

18. Tribun Jambi, Why are there 123 prohibition lubuks scattered in Bungo Regency, everywhere, https://jambi.tribunnews.com/2019/11/09/wikijambi (2019)

19. A.F. Andria, S. Rahmaningsih, J. Ilm. Perikan. Kelaut., 10, 2 (2018)

20. N.L. Saraswati, Yulias, A. Rustam, H.L. Salim, A. Heriati, E. Mustikasari, Jurnal Segara 13, 1 (2017). 